IBT Journal of Business Studies

Volume 14(2), 174-186, 2018

\title{
Talent and Talent Management: Definition and Issues
}

\author{
Novera Ansar \\ Akhtar Baloch ${ }^{2}$
}

\begin{abstract}
'Talent' has become a popular term amongst academicians and practitioners during the last two decades. A general problem, despite this increased interest on "Talent", is that the construct of Talent and Talent Management lack theoretical vigor and standardized definition. The aim of this paper is to make a contribution to the literature on "Talent" and "Talent Management" by a critical review of the construct of "Talent". The evolution of the definition of the term "Talent" was traced through different time periods starting from the Biblical Times when talent was used for a very large sum of money to the present times when it is considered as a cognitive ability. A philological perspective was also taken to identify the roots of different approaches towards "Talent" in speakers of different languages and terms, that are interchangeably used in lieu of Talent were also explored. Different definitions of the term "Talent Management" were analyzed to understand the different approaches taken by the authors. The dominant approach used in the definitions of Talent Management was found to be exclusive. The study concluded that it is important to develop a uniform definition of Talent and Talent Management for a shared understanding for both academic work on the topic and its practical implication for the corporate world.
\end{abstract}

Keywords: Talent, Talent Management

1- PhD Scholar, Department of Public Administration, University of Karachi, noveraansar@yahoo.com

2- Professor, PhD, Department of Public Administration, University of Karachi, abaloch@ uok.edu.pk 


\section{INTRODUCTION}

Talent is a desirable quality in all human beings and organizations need workers with the right "Talent". Technologists, inventors, entrepreneurs, artists, actors and actresses, singers, tenors, sports people, calligraphers, painters, teachers, speakers and people in many other fields have demonstrated excellent skills by virtue of being talented in that field. Talented people are scarce in number and business enterprises have always competed for this "rare resource". The mere presence of talent or talented workers does not ensure success / enhancement in performance. Organizations need to invest in proper utilization of the talent for the advantage of the organization. In other words, organizations need to "Manage Talent".

Talent Management (TM) as a term is not an entirely new invention and was used in a 1957 document of American Management Association(Dooher \& Marting, 1957). The term "Talent" was also used in business literature in the 1970s albeit sparsely, in works such as Talent waste (i.e. how institutions of learning misdirect human resources)(Ritterbush, 1972) andDeveloping Executive Talent: a practical guide (Mills, 1976) amongst others. The work by Mckinsey in 1998(Chambers, Foulon, HandfieldJones, Hankin, \& Michaels, 1998) however accelerated the research on talent management as a Google search on "Talent Management" generated 24.9 million in 2017 (Google, 2017) as compared to 5,750,000 result in 2007 (Christensen Hughes \& Rog, 2008) and 2,700,000 in 2004 (Felix \& Manuel, 2016).

Corporate requirements are an indispensible condition for this academic interest on Talent Management, and the discipline of Talent Management (TM) as a result has become a topic of interest for both practitioners and academicians (Gallardo-Gallardo, Thunnissen, \& Scullion, 2017). The increase in the global shortage of highly skilled workforce especially in the knowledge based sectors has also made the competition to hire and retain the necessary talent more difficult. As a result, the focus of Human Resource Management is on hiring and managing those employees considered most relevant to the long term interests of the companies or in other words employees who are "Talented" (Schuler, Jackson, \& Tarique, 2011).

The origin of the modern usage of the term goes backto as early as $19^{\text {th }}$ century (Chamorro-Premuzic, Von Stumm, \& Furnham, 2015)as cited by Tarique and Schuler (2012), when social science experts tried to articulate this concept and implement it in fields as varied as arts, early education and various sports. TM, as we know it today in the sphere of business competition and strategic management, was conceptualized by McKinsey's famous article titled "The War for Talent" that was published at the end of $20^{\text {th }}$ century, in 1998 (Handfield-Jones, Michaels, \& Axelrod, 2001). Following this ground breaking study, HR practitioners and academics from around the world realized the importance of this growing problem and subsequently TM has now become a specialist field within the HR domain with a steady output of research works being published annually on this topic (Scullion, Collings, \& Caligiuri, 2010; Silzer \& Dowell, 2010; Vaiman, 2010).

\section{Research Problem and Objective of the Study}

A general problem in studies on TM is that they have explored Talent with an implicit understanding that talent is important and will always lead to improvement in organizational and social performance. One word that repeatedly appears in the literature is the "Right" Talent and despite its frequency, the term "Right" is undefined since each organization will have a different context and requirements that will require a different "Right" talent. Due to this inherent understanding, the construct of Talent lack theoretical rigor in developing a definition of Talent. 
What is "Talent"? And what is "Talent" in the world of work? The question has not been answered with a standardized definition andthis lack of a standardized definition has created problem for both theoreticians and practitioners of talent for development of effective workable theoretical models and Talent Management plans. This deficiency of a clear definition is not only a problem for academicians or practitioners as it creates a conceptual issue but also that an absence of a definition makes it difficult to have a distinction between different terms; in this case difference between talent and other associated terms such as Ability, Capacity, Capability, Commitment, Competence, Contribution, Experience, Knowledge, Performance, Potential ,Skills ( sources mentioned in table 1) that have been often used or confused in lieu of Talent. The research papers that have focused on studying the concept or definition of talent are limited in the literature and in order to fill this research gap the objectiveof this paper is to carry out a critical review of the existing literature available on the construct of "Talent" for better understanding and conceptualization of talent and talent management for development of uniform talent management theories and model for effective implementation in the corporate world.

Academic and practitioner literature on Talent Management (TM) has defined talent with respect to their own contexts and thus there are a number of definitions of the term "(Gallardo-Gallardo, Dries, \& González-Cruz, 2013). Talent Management (TM) scholars have not been able to pin-point about talent since the construct of Talent is strongly influenced by their own implicit ideas and theories about it(Barab \& Plucker, 2002). These individual views have led to confusion amongst scholar on the meaning of "talent" and

The absence of a standard definition leads to a confusion since any writer could have a definition that suits their purpose and fits their context. Lewis and Heckman (2006) criticizes about this lack of consensus amongst researchers on defining Talent Management (TM), since it weakens establishing any research work on the subject. The article aims at developing an understanding of the term Talent for both scholars and practitioners for effective implementation of Talent Management. The article will first have a look at the historical treatment of the term before discussing its recent meanings in the literature on Talent Management.

\section{Talent: A brief History of the Term}

The word used in Old English for the term "Talent" was "Talente" and it was in usage until 1149 A.D, having its etymological base in Latin , "Talentum" "(Gallardo-Gallardo et al., 2013). "Talentum" has its roots in Greek " $\tau \alpha \dot{\lambda} \alpha v \tau$ ov" (talanton), meaning a balance or a monetary unit. Babylonians and Assyrians also used the same term for describing a monetary unit of a large amount of money (The amount could be equal to weekly salary) "(Gallardo-Gallardo et al., 2013).

Bible also used the same term to describe a monetary unit in a parable given in the Gospel of Matthew (25:14-30) mentioning that a very rich person gave "Talent" to his servants, for safekeeping, with respect to their capabilities before going for a long journey. Tansley (2011) opined that the term has since been also used for "Human Capital" which has been used to describe talent in the literature on Talent Management (TM), by researchers including Lepak and Snell (2007), Collings and Mellahi (2009), Boudreau and Ramstad (2005), andNagra (2011).

Talent changed its meaning during the 13th century when it was meant as a "feeling" or"inclination" towards something, or the natural skill of an individual. In the Middle Ages, "Talent" evolved and was understood to be a person's cognitive capability (Hoad, 1993). It was during the nineteenth century when talent was defined as a dichotomy of "Personal Talent" (talent viewed as a person or individual) and "Talent as an Ability" (talent viewed as a capability or skill possessed by an individual)(Tansley, 2011). 
Talent as a term has evolved from a word meaning "Weight" in ancient Greece and Rome (Tansley, 2011 ) to "Inborn Propensity or Capability" possessed by a person "(Gallardo-Gallardo et al., 2013). In organizational studies, the usual perspective towards defining talent is based on the exclusive approach (the exclusive approach assumes that there are only few gifted individuals that are star performers in an organization).

Axelrod, Handfield-Jones, and Michaels (2002) as cited by (Garavan, Carbery, \& Rock, 2012) have proposed a comprehensive definition of the term talent which is given below:

"A code for the most effective leaders and managers at all levels, who can help a company fulfill its aspirations and drive its performance. Managerial talent is some combination of a sharp strategic mind, leadership ability, emotional maturity, communications skills, and the ability to attract and inspire other talented people, entrepreneurial instincts, fundamental skills and the ability to deliver results".

McKinsey's study came to the conclusion that the resource structure of the future corporate world would consider technically superior, globally knowledgeable and operationally active professionals as their most important resource and these people would be smart and professional workers. McKinsey defined talent as "a sum of the person's abilities... his or her intrinsic gifts, skills, knowledge, experience, judgment, drive and ability to learn”(Handfield-Jones et al., 2001).

\section{Impact of "Culture" on the meaning of "Talent"}

Each culture has provided its own unique interpretation of the term talent and its understanding explains how speakers of a particular culture take a specific perspective towards talent (perspectives include exclusive/inclusive and subject/object). Two cultures, European and Japanese, present an interesting example. European languages (English, Russian, Polish and French) consider talent to be an innate factor, whereas Japanese language specifies talent to be as an accomplishment yet to be achieved(Tansley, 2011).

This discussion establishes that talent is conceptualized as an "innate" factor in the European languages and it is an acquired accomplishment in the Japanese language. Out of all the definitions that were studied during the course of preparation of this thesis, a common denominator was that "Talent" is the possession by an individual of certain attributes or behavior (things that an individual does more efficiently or easily than others around him / her) that make the individual 'right' for that particular role. The management of talent inherently defines those systems or processes which enable organizations to identify and predict long / short term human capital requirements and how to fulfill the same. The major portion of work on TM deals with management and top level positions but the field of TM applies to all the positions in an organization that are key to its functioning and are relatively harder to fill.

Talent is not the only term that describes people with exceptional ability or gifted qualities to achieve extra ordinary accomplishments. There are other terms such as gifted, able, or promising that are used to describe people with high levels of achievement. "Gallardo-Gallardo et al. (2013) elaborated the following terms that are related to or used in place of Talent Management (TM). These terms are explained in table 1 below. 
IBT Journal of Business Studies

\begin{tabular}{|c|c|c|}
\hline & & Table 1 \\
\hline \multicolumn{3}{|c|}{ Talent Management (TM) Related Terms } \\
\hline $\begin{array}{l}\text { Related } \\
\text { Terms }\end{array}$ & Sources used & Title of Publication \\
\hline Ability & $\begin{array}{l}\text { Rob Silzer and } \\
\text { Dowell (2010) }\end{array}$ & Strategy-driven Talent Management: A Leadership Imperative. \\
\hline Capacity & Rodríguez (2001) & $\begin{array}{l}\text { La gestión del talento: Enfoque conceptual y empírico. Boletín de } \\
\text { Estudios Económicos, as cited by (Gallardo-Gallardo et al., 2013). }\end{array}$ \\
\hline Capability & Stahl et al. (2007) & $\begin{array}{l}\text { Global Talent Management: How Leading Multinationals Build And } \\
\text { Sustain Their Talent Pipeline. }\end{array}$ \\
\hline Commitment & $\begin{array}{l}\text { Younger et al. } \\
(2007)\end{array}$ & Developing Your Organization's Brand As A Talent Developer. \\
\hline Competence & $\begin{array}{l}\text { Bethke-Langenegger } \\
\text { P (2012) }\end{array}$ & $\begin{array}{l}\text { The Differentiated Workforce: Effects Of Categorization In Talent } \\
\text { Management On Workforce Level. }\end{array}$ \\
\hline Contribution & $\begin{array}{l}\text { Younger et al. } \\
(2007)\end{array}$ & $\begin{array}{l}\text { The Differentiated Workforce: Effects Of Categorization In Talent } \\
\text { Management On Workforce Level. }\end{array}$ \\
\hline Experience & Cheese (2007) & $\begin{array}{l}\text { The Talent Powered Organization: Strategies For Globalization, Talent } \\
\text { Management And High Performance. }\end{array}$ \\
\hline Knowledge & $\begin{array}{l}\text { Bethke-Langenegger } \\
\text { P (2012) }\end{array}$ & $\begin{array}{l}\text { The Differentiated Workforce: Effects Of Categorization In Talent } \\
\text { Management On Workforce Level. }\end{array}$ \\
\hline Performance & Tansley et al. (2007) & Talent: Strategy, Management, Measurement \\
\hline Potential & Tansley et al. (2007) & Talent: Strategy, Management, Measurement. \\
\hline Skills & $\begin{array}{l}\text { Rob Silzer and } \\
\text { Dowell (2010) }\end{array}$ & Strategy-Driven Talent Management: A Leadership Imperative. \\
\hline & & es" and "Title" c \\
\hline
\end{tabular}

\section{Competency}

Competency means a "Skilled Behavior" and this behavior becomes a competency when the individual exhibits it. The term "Competence" means "Standards of Performance" (Hoffmann, Kafatos, Janeway, \& Ezekowitz, 1999). According to Katz and Kahn (1978) there are four main different types of competencies:

1) Technical or functional (such as working with machines or new softwares)

2) Managerial (planning, organizaing, staffing and controlling)

3) Human (ability to work with other workers)

4) Conceptual (ability of visualizations of the future scenarios and abstract imaginations). 
Competency models describe how knowledge, skills and personal characteristics of workers are combined for effective performance needed in organizations and these models also act as an aid for HR department to select, train, develop, and appraise and plan for succession(McLagan, 1989).

Capacity

As with the term 'talent' earlier discussed, the term "Capacity" also faces the difficulty of a standardized understanding among scholar. Different authors view the definition of capacity with different perspectives. Most of the academics and practitioners view it as an HR issue with specific training and skill development so that the employees are better able to deliver or implement policies / procedures (Alsop \& Kurey, 2005). The United Nations Development Programme defines the term capacity as "The ability of individuals, institutions, and societies to perform functions, solve problems, and set and achieve objectives in a sustainable manner"(UNDP, 2009).

Practically, the word "Capacity" is synonymous with "Ability"; the ability to perform effectively, deliver efficiently, and add value (or in other words to make a positive contribution towards the strategic goal of the organization). Because it is mostly based on potential or intangibles, capacity is considered a latent factor as opposed to performance which can be highly tangible and measureable. This is why it is difficult to quantify and measure capacity.

Capacities - whether individual, institutional or social - must and do change over a period of time(Singh, 2012). Therefore, individuals' capacity transformation forms an important part of an organization's TM, making it more wholesome by enhancing employee potential through development.

Potential

"Potential" is a latent, intangible quality showing the capability to develop into something useful in the future and lead to success. This definition is true for individuals, organizations, and even society as a whole. Within the context of TM, potential specifically refers to the capacity of an individual having the ability to develop in line with the organizational goals and prove useful when the need arises. Individual employees perceived as possessing a high level of potential not only outperform others in different environments and scenarios but also show strong and consistent capacity to grow and succeed in line with the organization's culture and objectives (Ready, Conger, and Hill, 2010).

The fact that some individuals are more talented or able than their peers is disputed by very few. However, the real point of debate is about the type and nature of treatment these 'high potentials' receive. As TM applies to the management of a selected group for key positions, the application of strong ethical models is essential to not only groom talent but also maintain loyalty and appropriate career development options for other employees. As a rule, a good TM model should not only identify potential and measure performance but must also have protocols in place to ascertain how these individuals have achieved that performance and made their mark.

Performance

"Performance" can be defined in many ways e.g. the completion by an individual, company, or group of a task against known preset standards of quality, quantity, cost effectiveness, and efficiency. In other words, performance is the total effectiveness of an employee or company against well-defined standards which include output, availability and reliability, response time, and cost efficiency.

Many setups working under different conditions fail to clearly differentiate between the idea of performance versus potential(Silzer \& Church, 2009; Wellins, Smith, \& Erker, 2009). Performance is more tangible, relatively easily identifiable, quantifiable, measureable, and comparatively short term. Potential on the other hand is latent, and presents the long term ability to consistently perform and improve. High performers may be good today, but may not necessarily be equipped to handle future 
changes. Because performance and potential are not mutually exclusive, it is all too common to confuse a high-performer for a high-potential person, and more often than not this proves costly.

Good performing employees consistently exceed expectations, and are regularly given tough assignments because of their track record and a 'can do' attitude'. However, it is quite possible that these employees may lack the potential or desire to be equally successful if they were promoted to a higher post or if they were given a more complex or advanced work especially in leadership roles. High potentials on the other hand are marathon runners. They are difficult to identify because they possess less obvious attributes and behaviors like change management, adaptability, or learning capabilities. Also, very few businesses are able to precisely lay down guidelines to identify and assess the competencies they are looking for in their employees. Consequently, evaluators - being unclear about the specific standards or evaluation criteria - fall prey to the tendency of measuring potential by looking at the most visible and tangible attribute i.e. employee performance(Lagunas, 2012).

\section{Definitions of Talent Management}

The subject of Talent Management (TM) is an established field with growing importance; however, there is no convergence of scholarly opinions regarding its objective definition. The very concept of managing the desired talent poses theoretical challenges and lacks clarity. A broad overview of the available literature reveals that existing definition in the current literature have not succeeded in developing a clear distinction between Talent Management (TM) and other sub-functions of Human Resource Management. A number of different related terms (as discussed above in the section on related terms) are frequently used to denote talent, and this raises additional conceptual problems (Iles, Chuai, and Preece (2010), and Cappelli (2008).

One distinction between HRM and TM may be drawn based on the work of(Barney, 1991). Barney explains that Talent Management (TM) relatively focuses more on the human side of the work and considers talented workers as a competitive advantage of organizations while HRM takes all of organizational function into consideration. Talent Management (TM) aims at developing human talent of the organization whereas HRM is more technical and uses transactional approach. Blass (2009) developed a diagrammatical model of territory of Talent Management (TM) and how it is composed of different factors as given in the figure 1.

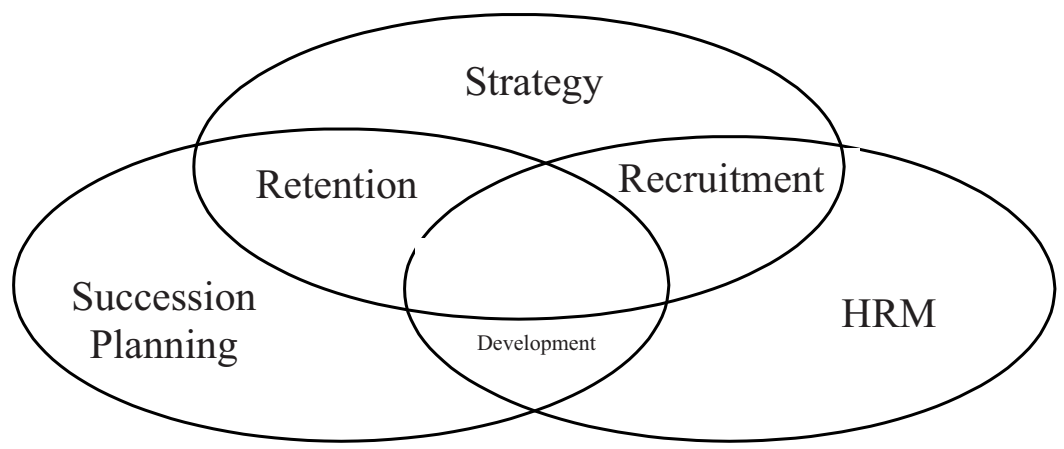

Figure 1 Diagram on Talent Management (TM) Territory. Reprinted from Defining Talent from Talent Management (pp. 24 
Other scholars on TM took a similar view and included attraction, identification, deployment, development and engagement of the work force as the key elements of Strategic Talent Management. (Bish \& Jorgensen, 2016; Blass, 2009; Cheese, 2010; Uren, 2007).

Global interest in TM has spurned research work on the subject and studies have been published in several countries such as Pakistan(Bano, Khan, Rehman, \& Humayoun, 2011; Rana \& Abbasi, 2013), India (Anand, 2011; Tymon, Stumpf, \& Doh, 2010), South Africa (Koketso \& Rust, 2012), Thailand(Piansoongnern, Anurit, \& Kuiyawattananonta, 2011), and China (Preece, Iles, \& Chuai, 2011). Review of the literature reveals that in all these countries TM is a recent entrant into the HR field and is being dealt by the practitioners in many different ways much the same as their counterparts in USA or elsewhere.

Lewis and Heckman (2006) discussed the problem of defining TM in one of the first major critical reviews on Talent Management. The review took a thematic perspective towards Talent Management (TM) and explained that Talent Management (TM) researchers have taken three clear perspectives on its definition. The first perspective taken by scholars focused on mechanical characteristics and it was a rebranding effort. The rebranding is of already established terms such as Human Resource Management, recruitment, selection, leadership development and executive succession planning. This approach considers that TM is a new label for the old practice of Human Resource Management. The first perspective thus takes the view that Talent Management (TM) is a new tern for HRM or in other words, a rebranding of old HRM brand, or a new effort at doing HR in a better way.

The second perspective emphasized on developing "Talent Pools" andthe studies influenced by this perspective had a conceptual issue since they tend to describe Talent Management (TM) similar to the concept of "Succession Planning". This perspective takes talent pools as a mechanism to ensure a regular supply of able workers so that current and possible future requirements are met without any hindrance. It also focuses on only one aspect of Talent Management (TM) and puts less emphasis on its other aspects and thus, may be termed as a Myopic Perspective(Collings \& Mellahi, 2009; Lewis \& Heckman, 2006).

The third perspective has a subject approach towards talent (Subject approach considers "people" to be "talent" rather than "talent" being their "characteristic". When talent is defined as a characteristic of workers, it is termed as object approach). The third perspective may be further sub-divided in two approaches; exclusive approach and inclusive approach. The exclusive approach suggests that talent is exclusive to only a few "talented" individuals and thus it is limited. Exclusivity is limited to "A" players or "Top Performers". The exclusive approach calls for a forced filling of organization with top grading performers and phasing out of " $\mathrm{C}$ " performers (C performers are the ones not meeting the desired performance standards) from the organizations.

On the other hand, inclusive approach considers that all employees are talented and an organizationwide effort is needed to encourage people to explore and improve their talent by providing opportunities to all the employees (Lewis \& Heckman, 2006; Michaels, Hanfield-Jones, \& Axelrod, 2001; Smart, 2005). Branham (2001) is of the opinion that talent is not a rare commodity i.e. everyone possesses some kind of a talent, which can be utilized in different scenarios.

These perspectives have been instrumental in developing a definition of Talent Management (TM) and have given varying degree of importance to different aspects of Talent Management. The existing literature is full of examples of a strong influence of the exclusive approach even though some authors have conceptualized inclusive Talent Management (TM) and considered this approach to be an important one(Ford, Harding, \& Stoyanova Russell, 2010; Swailes, Downs, \& Orr, 2014). 
The dominating perspective, exclusive and subject, leads to the belief that talent is innate, only few are gifted by birth and therefore, not everyone can be titled as talented. This approach is the prevailing one and can be found in the work of (Bethke-Langenegger P, 2012; Gagne, 2000; Françoys Gagné, 2000, 2004; Francoys Gagné, 2005; Michaels et al., 2001; Silzer \& Dowell, 2010; A. M. Williams, 2000; M. R. Williams, 2000). This prevalent and leading perspective has also influenced how Talent Management (TM) is defined in the academic literature (Slan-Jerusalim \& Hausdorf, 2007) and emphasizes that employees that are talented should be developed and given important roles and positions in the organizations. Duttagupta (2005) took a different position in defining Talent Management (TM) and elucidated it as the flow of talent in an organization to meet the requirement of the talented workers as per the business needs.

The above mentioned scholars' work identifies the reliance of researchers on the exclusive approach to conceptualize talent. It was Collings and Mellahi (2009) who shifted emphasis of the definition from "People" or "Characteristics" to "Position" and "Role". They included "Key Positions" in the definition of Talent Management (TM) and claimed that these "Positions" influence the competitive advantage that a firm has over other organizations. This new perspective may be the fourth emerging perspective in the field and help organizations create more efficient organizational structures that make use of these positions for improved organizational performance.

Application of different perspectives in defining Talent Management (TM) and the role of this definition in shaping academicians and managers' attitude and practice towards Talent Management (TM) points to the fact that it is not a field in isolation. It has a strong business purpose and thus needs to be aligned with the needs of the market.

Tarique and Schuler (2012) have compiled a summary of the TM definitions mostly appearing across the spectrum of TM literature and the salient highlights of those definitions include:

a. TM is merely an extension of the HR sub-functions and the term is used interchangeably with HRM.

b. $\quad$ TM is more strategic in nature and it focuses on the future requirement in the workers' capabilities that will meet future needs of the business.

c. TM is selective and focuses on key positions, which are perceived by the management as vital for developing long term competitive edge for any business.

d. TM is based on a capability and capacity building approach to strategic HRM.

The table A given in the appendix is the compilation of definitions of TM. The table has been compiled chronologically and lists author and year of publication, title of the publication, definition of "Talent Management" and the focus (approach, theme) of the definition.

A careful review of the above and some other definitions reveal several common patterns across the literature.

1. Firstly, the TM process identifies itself with individuals who are perceived to possess critically required, value enhancing talents for the organization.

2. And secondly, HRM policies and practices which specially focus on hiring, retaining, and developing these individuals to better serve organizational goals.

In light of the above, TM as a concept, may be elaborated as strategically oriented HR policies and processes to manage individuals with extraordinary required capabilities or talent needed by the organization(Tarique \& Schuler, 2010). Talent Management (TM) thus, emphasizes development and effective employment of corporate strategies for effective utilization of the talent pool to ensure a 
continuous supply of talent to meet its short / long term objectives, and overall activities of the organization are in harmony with its TM processes(Garavan et al., 2012).

Different definitions of Talent Management (TM), as given in the appendix in table A, indicate different approaches to study talent. These definitions are academic in nature but few studies have also identified that organizations also develop their own definitions of talent. For example, the 2004 Towers Perrins' survey showed that 80 percent of the companies surveyed used an official standardized talent definition throughout the organization. However, none of these companies used the same talent definition demonstrating that the talent definition is adopted depending on the organizations' business strategy, the type of the firm, the overall competitive environment and other factors (Iles, et al., 2010a; CIPD, 2007) (CIPD refers to Chartered Institute of Personnel and Development based in United Kingdom). Knowing different ways that the term "Talent" can be defined or operationalized helps to increase the understanding of how it can be used and can provide new directions for the future research. In practice, how firms define "Talent" impacts their TM strategy and practices directly (Meyers, et al., 2013).

\section{CONCLUSION}

The author of the study concludes that "Talent" is still in evolutionary stages and is yet to be established as a separate construct in the business literature so that other terms are not used in its place and vice-e-versa. It is critical for Talent to be accepted as an independent concept so that academicians, authors, researchers, practitioners and readers develop shared meaning of the term. Without this shared meaning, the phenomena of Talent and Talent Management would advance towards becoming a discipline with better theoretically grounded

\section{REFERENCES}

Alsop, R., \& Kurey, B. (2005). Local organizations in decentralized development: Their functions and performance in India: World Bank Publications.

Anand, P. (2011). Talent development and strategy at telecom major Bharti Airtel. Strategic HR Review, 10(6), 25-30.

Ashton, C., \& Morton, L. (2005). Managing talent for competitive advantage: Taking a systemic approach to talent management. Strategic HR Review, 4(5), 28-31.

Axelrod, B., Handfield-Jones, H., \& Michaels, E. (2002). A new game plan for C players. Harvard Business Review, 80(1), 80-90.

Bano, S., Khan, M. A., Rehman, Q. H. U., \& Humayoun, A. A. (2011). Schematizing talent management, a core business issue. Far East Journal of Psychology and Business, 2(1), 4-16.

Barab, S. A., \& Plucker, J. A. (2002). Smart people or smart contexts? Cognition, ability, and talent development in an age of situated approaches to knowing and learning. Educational psychologist, 37(3), 165-182.

Barney, J. (1991). Firm resources and sustained competitive advantage. Journal of management, $17(1), 99-120$.

Bethke-Langenegger P. (2012). The differentiated workforce-effects of categorisation in talent management on workforce level. Unpublished working paper, 18.

Bish, A., \& Jorgensen, F. (2016). Employee perceptions of the talent management message: Case analyses in Danish SMEs.

Blass, E. (2009). Defining Talent Talent Management (pp. 24-36): Springer.

Boudreau, J. W., \& Ramstad, P. M. (2005). Talentship, talent segmentation, and sustainability: A new HR decision science paradigm for a new strategy definition. Human Resource Management, 44(2), 129-136.

Cappelli, P. (2008). Talent management for the twenty-first century. Harvard business review, 86(3), 
74.

Chambers, E. G., Foulon, M., Handfield-Jones, H., Hankin, S. M., \& Michaels, E. G. (1998). The war for talent. McKinsey Quarterly, 44-57.

Chamorro-Premuzic, T., Von Stumm, S., \& Furnham, A. (2015). The Wiley-Blackwell handbook of individual differences (Vol. 3): John Wiley \& Sons.

Cheese, P. (2010). Talent management for a new era: what we have learned from the recession and what we need to focus on next. Human Resource Management International Digest, 18(3), 35.

Christensen Hughes, J., \& Rog, E. (2008). Talent management: A strategy for improving employee recruitment, retention and engagement within hospitality organizations. International Journal of Contemporary Hospitality Management, 20(7), 743-757.

Collings, D. G., \& Mellahi, K. (2009). Strategic talent management: A review and research agenda. Human Resource Management Review, 19 (4), $304-313$. doi:https://doi.org/10.1016/j.hrmr.2009.04.001

Dooher, M. J., \& Marting, E. (1957). Selection of management personnel (Vol. 1): American Management Association.

Duttagupta, R. (2005). Identifying and managing your assets: Talent management. PricewaterhouseCoopers, London.

Felix, C., \& Manuel, J. (2016). Talent Management Through the Management Fashion Lens.

Ford, J., Harding, N., \& Stoyanova Russell, D. (2010). Talent management at the NHS Yorkshire and the Humber.

Gagne, F. (2000). Understanding the complex choreography of talent development through DMGTbased analysis. International handbook of giftedness and talent, 2, 67-79.

Gagné, F. (2000). A differentiated model of giftedness and talent (DMGT). Systems and models for developing programs for the gifted and talented.

Gagné, F. (2004). Transforming gifts into talents: The DMGT as a developmental theory. High ability studies, 15(2), 119-147.

Gagné, F. (2005). From gifts to talents. Conceptions of giftedness, 2, 98-119.

Gallardo-Gallardo, E., Dries, N., \& González-Cruz, T. F. (2013). What is the meaning of 'talent'in the world of work? Human Resource Management Review, 23(4), 290-300.

Gallardo-Gallardo, E., Thunnissen, M., \& Scullion, H. (2017). Special issue of International Journal of Human Resource Management. A contextualized approach to Talent Management: Advancing the field. The International Journal of Human Resource Management, 1-4. doi:10.1080/09585192.2016.1275292

Garavan, T. N., Carbery, R., \& Rock, A. (2012). Mapping talent development: definition, scope and architecture. European Journal of Training and Development, 36(1), 5-24. Google. (2017). Talent Managment. Retrieved from https:/www.google.com/search?client=firefox-bab\&ei $=4 \mathrm{WgSWrSgFcG7UZegnEg \& q}=$ talent + management\&oq $=$ talent + management\&gs

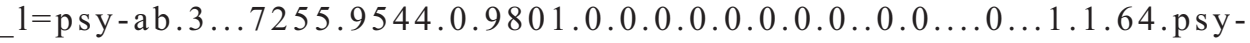
$\overline{a b} . .0 .0 .0 \ldots .0 . H p v g 31 \mathrm{Uza0} 0$

Handfield-Jones, H., Michaels, E., \& Axelrod, B. (2001). The war for talent: Boston: Harvard Business School Publishing.

Hoad, T. F. (1993). The concise Oxford dictionary of English etymology: Oxford University Press Oxford.

Hoffmann, J. A., Kafatos, F. C., Janeway, C. A., \& Ezekowitz, R. (1999). Phylogenetic perspectives in innate immunity. Science, 284(5418), 1313-1318.

Iles, P., Chuai, X., \& Preece, D. (2010). Talent management and HRM in multinational companies in Beijing: Definitions, differences and drivers. Journal of World Business, 45(2), 179-189.

Katz, D., \& Kahn, R. L. (1978). The social psychology of organizations (Vol. 2): Wiley New York.

Koketso, L. P., \& Rust, A. B. (2012). Perceived challenges to talent management in the South African public service: An exploratory study of the City of Cape Town municipality. African Journal of Business Management, 6(6), 2221. 
Lagunas, K. (2012). Five employee retention strategies for a higher performance environment. TLNT, The Business of HR.@,TLNT.Com.

Lepak, D., \& Snell, S. A. (2007). Employment subsystems and the'HR architecture'. Oxford Handbook of Human Resource Management, The, 210.

Lewis, R. E., \& Heckman, R. J. (2006). Talent management: A critical review. Human Resource Management Review, 16(2), 139-154.

McLagan, P. A. (1989). Models for HRD practice. Training \& Development Journal, 43(9), 49-60.

Michaels, E., Hanfield-Jones, H., \& Axelrod, B. (2001). The War for Talent (Harvard Business School Press, Boston, MA). Google Scholar.

Mills, L. (1976). Developing executive talent: Terry Farnsworth, McGraw-Hill, Maidenhead (1975), 162 pp.£ 4.50 (hardback): Pergamon.

Nagra, M. (2011). Human capital strategy: Talent management. US Army Medical Department Journal, 31-38.

Pascal, C. (2004). Talent management systems: Best practices in technology solutions for recruitment, retention, and workforce planning. Wiley: Canada.

Piansoongnern, O., Anurit, P., \& Kuiyawattananonta, S. (2011). Talent management in Thai cement companies: A study of strategies and factors influencing employee engagement. African Journal of Business Management, 5(5), 1578.

Preece, D., Iles, P., \& Chuai, X. (2011). Talent management and management fashion in Chinese enterprises: exploring case studies in Beijing. The International Journal of Human Resource Management, 22(16), 3413.

Rana, A. H., \& Abbasi, A. S. (2013). Impact of Talent Management and Employee Turnover Intention on Organizational Efficiency - A case of Telecommunication Sector of Pakistan. Science International, 25(3).

Ritterbush, P. C. (1972). Talent waste: how institutions of learning misdirect human resources: Acropolis Books.

Schuler, R. S., Jackson, S. E., \& Tarique, I. (2011). Global talent management and global talent challenges: Strategic opportunities for IHRM. Journal of World Business, 46(4), 506-516.

Scullion, H., Collings, D. G., \& Caligiuri, P. (2010). Global talent management. Journal of World Business, 45(2), 105-108. doi:https://doi.org/10.1016/j.jwb.2009.09.011

Silzer, R., \& Church, A. H. (2009). The pearls and perils of identifying potential. Industrial and Organizational Psychology, 2(4), 377-412.

Silzer, R., \& Dowell, B. E. (2010). Strategic talent management matters. Strategy-driven talent management: Aleadership imperative, 3-72.

Singh, M. (2012). Talent management by capacity building of the employees. International Journal of Knowledge and Research in Management \& e-Commerce, 2(4).

Slan-Jerusalim, R., \& Hausdorf, P. A. (2007). Managers' justice perceptions of high potential identification practices. Journal of Management Development, 26(10), 933-950.

Sloan, E. B., Hazucha, J. F., \& Van Katwyk, P. T. (2003). Strategic management of global leadership talent Advances in global leadership (pp. 235-274): Emerald Group Publishing limited.

Smart, B. D. (2005). Topgrading: How leading companies win by hiring, coaching, and keeping the best people: Penguin.

Swailes, S., Downs, Y., \& Orr, K. (2014). Conceptualising inclusive talent management: potential, possibilities and practicalities. Human Resource Development International, 17(5), 529544.

Tansley, C. (2011). What do we mean by the term "talent" in talent management? Industrial and commercial training, 43(5), 266-274.

Tarique, I., \& Schuler, R. (2012). Global talent management literature review. White paper: SHRM Foundation.

Tarique, I., \& Schuler, R. S. (2010). Global talent management: Literature review, integrative framework, and suggestions for further research. Journal of World Business, 45(2), 122-133.

Tymon, W. G., Stumpf, S. A., \& Doh, J. P. (2010). Exploring talent management in India: The 
neglected role of intrinsic rewards. Journal of World Business, 45(2), 109-121.

UNDP, I. (2009). Capacity Development: a UNDP primer. New York: UNDP.

Uren, L. (2007). From talent compliance to talent commitment: Moving beyond the hype of talent management to realizing the benefits. Strategic HR Review, 6(3), 32-35.

Vaiman, V. (2010). Talent management of knowledge workers: Embracing the non-traditional workforce: Springer.

Warren, C. (2006). Curtain call. Retrieved from http://www2.cipd.co.uk/pm/peoplemanagement/b/weblog/archive/2013/01/29/curtaincall2006-03.aspx\#

Wellins, R. S., Smith, A. B., \& Erker, S. (2009). Nine best practices for effective talent management. Development dimensions international, 1-14.

Williams, A. M. (2000). Perceptual skill in soccer: Implications for talent identification and development. Journal of sports sciences, 18(9), 737-750.

Williams, M. R. (2000). The war for talent: Getting the best from the best: CIPD Publishing.

\section{Appendix}

\begin{tabular}{|c|c|c|c|}
\hline \multicolumn{4}{|c|}{ Table A } \\
\hline \multicolumn{4}{|c|}{ Definitions of Talent Management (TM) } \\
\hline $\begin{array}{l}\text { Author and } \\
\text { Year of the } \\
\text { Publication }\end{array}$ & Title of the Publication & Definition of TM & Focus of the Definition \\
\hline $\begin{array}{l}\text { Sloan, Hazucha, } \\
\text { and Van Katwyk } \\
\text { (2003) }\end{array}$ & $\begin{array}{l}\text { Strategic management of global } \\
\text { leadership talent Advances in } \\
\text { global leadership }\end{array}$ & $\begin{array}{l}\text { "Managing leadership talent strategically, to put the right person in the right } \\
\text { place at the right time" (P. 236) }\end{array}$ & $\begin{array}{l}\text { Talent Management (TM) is all about } \\
\text { being right. Right person, right place and } \\
\text { right time. }\end{array}$ \\
\hline Pascal (2004) & $\begin{array}{l}\text { Talent management systems: } \\
\text { Best practices in technology } \\
\text { solutions for recruitment, } \\
\text { retention, and workforce } \\
\text { planning }\end{array}$ & $\begin{array}{l}\text { "Talent Management (TM) encompasses managing the supply, demand, and } \\
\text { flow of talent through the Human Capital Engine" (p.9) }\end{array}$ & $\begin{array}{l}\text { Talent Management (TM) means meeting } \\
\text { the needs of the organization through } \\
\text { efficient and effective supply of talented } \\
\text { workforce as and when needed. }\end{array}$ \\
\hline $\begin{array}{l}\text { Ashton and } \\
\text { Morton (2005) }\end{array}$ & $\begin{array}{l}\text { Managing talent for competitive } \\
\text { advantage: Taking a systemic } \\
\text { approach to talent management. }\end{array}$ & $\begin{array}{l}\text { "TM is a strategic and holistic approach to both HR and business planning or } \\
\text { a new route to organizational effectiveness. This improves the performance } \\
\text { and the potential of" people-the talent" who can make a measurable } \\
\text { difference to the organization now and in the future. And it aspires to yield } \\
\text { enhanced performance among all levels in the workforce, thus allowing } \\
\text { everyone to reach his/her potential, no matter what that might be" (p.30) }\end{array}$ & $\begin{array}{l}\text { An inclusive approach towards talent } \\
\text { management. }\end{array}$ \\
\hline $\begin{array}{l}\text { Duttagupta } \\
\text { (2005) }\end{array}$ & $\begin{array}{l}\text { Identifying and managing your } \\
\text { assets: Talent management. }\end{array}$ & $\begin{array}{l}\text { "In the broadest possible terms, TM is the strategic management of the flow } \\
\text { of talent through an organization. Its purpose is to assure that a supply of } \\
\text { talent is available to align the right people with the right jobs at the right time } \\
\text { based on strategic business objectives" (p.2) }\end{array}$ & $\begin{array}{l}\text { This definition is influenced by (Sloan et } \\
\text { al., 2003) and (Pascal, 2004). }\end{array}$ \\
\hline Warren (2006) & Curtain Call & $\begin{array}{l}\text { "In the broadest sense, the term can be seen as the identification, } \\
\text { development, engagement, retention and deployment of talent, although it is } \\
\text { often used more narrowly to describe the short - and longer- term resourcing } \\
\text { of senior executives and high performers" (p.26) }\end{array}$ & $\begin{array}{l}\text { This definition encapsulates Talent } \\
\text { Management (TM) as a function of } \\
\text { identification, development, engagement, } \\
\text { retention and deployment of talent. }\end{array}$ \\
\hline $\begin{array}{l}\text { Slan-Jerusalim } \\
\text { and Hausdorf } \\
\text { (2007) }\end{array}$ & $\begin{array}{l}\text { Managers' justice perceptions of } \\
\text { high potential identification } \\
\text { practices. }\end{array}$ & $\begin{array}{l}\text { "High potential identification and development (also known as Talent } \\
\text { Management) refers to the process by which an organization identifies and } \\
\text { develops employees who are potentially able to move into leadership roles } \\
\text { sometime in the future" (p. 934) }\end{array}$ & $\begin{array}{l}\text { This definition focuses on two aspects of } \\
\text { talent management; namely, identification } \\
\text { and development of talent. }\end{array}$ \\
\hline Cappelli (2008) & $\begin{array}{l}\text { Talent Management for the } \\
\text { twenty-first century }\end{array}$ & $\begin{array}{l}\text { "At its heart, Talent Management (TM) is simply a matter of anticipating the } \\
\text { need for Human Capital and setting out a plan to meet it" (p.1) }\end{array}$ & $\begin{array}{l}\text { This definition is influenced by concepts } \\
\text { of talent pool and succession planning and } \\
\text { also by (Pascal, 2004) }\end{array}$ \\
\hline $\begin{array}{l}\text { Collings and } \\
\text { Mellahi (2009) }\end{array}$ & $\begin{array}{l}\text { Strategic talent management: A } \\
\text { review and research agenda }\end{array}$ & $\begin{array}{l}\text { "We define Strategic Talent Management (TM) as activities and processes } \\
\text { that involve the systematic identification of Key Positions which } \\
\text { differentially contribute to the organization's sustainable competitive } \\
\text { advantage, the development of a talent pool of high potentials and high- } \\
\text { performing incumbents to fill these roles, and the development of a } \\
\text { differentiated human resource architecture to facilitate filling these positions } \\
\text { with competent incumbents and to ensure their continued commitment to the } \\
\text { organization" (p.2) }\end{array}$ & $\begin{array}{l}\text { This definition introduced the concept of } \\
\text { Key Position in Talent Management (TM) } \\
\text { literature. This definition further } \\
\text { suggested that TM is a process based } \\
\text { approach. }\end{array}$ \\
\hline $\begin{array}{l}\text { Silzer and } \\
\text { Dowell (2010) }\end{array}$ & $\begin{array}{l}\text { Strategic Talent Management } \\
\text { matters. Strategy-driven talent } \\
\text { management: A leadership } \\
\text { imperative }\end{array}$ & $\begin{array}{l}\text { "Talent Management (TM) is an integrated set of processes, programs, and } \\
\text { cultural norms in an organization designed and implemented to attract, } \\
\text { develop, deploy, and retain talent to achieve strategic objectives and meet } \\
\text { future business needs" (p.18) }\end{array}$ & $\begin{array}{l}\text { This definition is strategic in nature and } \\
\text { aims at making Talent Management (TM) } \\
\text { an integral part of organizational culture. }\end{array}$ \\
\hline
\end{tabular}

